\title{
Teaching Special Education Law in Saudi Arabia: Improving Pre-Service Teacher Education and Services to Students with Disabilities
}

\author{
Francie Murry ${ }^{1, *} \&$ Ragea Mohammed Ali Alqahtani ${ }^{2}$ \\ ${ }^{1}$ School of Special Education, University of Northern Colorado, Greeley, Colorado, USA \\ ${ }^{2}$ Najran University, University City King Abdulaziz Street, Saudi Arabia \\ *Correspondence: School of Special Education, University of Northern Colorado, McKee Hall Office 33, Greeley, \\ Colorado 80639, USA. Tel: 1-970-351-1656. E-mail: francie.murry@unco.edu
}

$\begin{array}{ll}\text { Received: October 9, } 2015 & \text { Accepted: November 20, } 2015 \quad \text { Online Published: December 8, } 2015 \\ \text { doi:10.5430/wje.v5n6p57 } & \text { URL: http://dx.doi.org/10.5430/wje.v5n6p57 }\end{array}$

\begin{abstract}
The government of Saudi Arabia has devoted considerable financial resources toward the education for all goal and in future generations through emphasizing the importance of education and increasing the accountability of teachers' performance on their students' performance. It has emphasized education is to be "Education for All". These demands require teachers who are presently working to adjust to new knowledge, legislation, and policies within the education fields. The purpose of this study was to examine the knowledge of pre-service teachers graduating from a major teacher preparation university in Saudi Arabia in regards to special education laws and implementation of educational programs for students with disabilities. Results indicate that pre-service teacher in Saudi Arabia want information on the special education law, Law Number 224, and how to implement it in their schools.
\end{abstract}

Keywords: Special education; Law number 224; Saudi Arabian Pre-service education

\section{Introduction}

\subsection{Introduce the Problem}

The government of Saudi Arabia has emphasized education is to be "Education for All". In the past the Saudi education system, similar to the Saudi economy, was heavily dependent on foreign skilled labor; however, in the last ten years there has been a substantial effort to train indigenous people as teachers for students with special education needs (Alquraini, 2011; Rugh, 2002). The Kingdom of Saudi Arabia has devoted considerable financial resources toward the goal of educating all and has emphasized the importance of education for future generations by increasing the accountability of pre-service teachers' performance (Almadina Newspaper, 2011; Al-Mousa, 2010). These demands require pre-service teachers who are presently being educated to acquire knowledge about current legislation and policies within the education fields. The push to promote the improvement of education for all has resulted in the need to create a sense of responsibility and a culture of accountability for effective teaching (Altayar, 2003). Requiring the demonstration of teaching accountability and outcomes in Saudi Arabia is similar to historical events in United States that brought about laws for special education. Much of what is changing in special education in Saudi Arabia mirrors what occurred in the United States over the past 40 years. These changes include teacher education to reconsider how they address professional standards and basic skill tests for teaching applicants in Saudi Arabian university classrooms (Alnahdi, 2014).

Currently teachers use the essential curricular guides for their area of content teaching. The compulsory curriculum for all students attending schools in Saudi Arabia leaves little room for the individualization of students with specialized needs within their neighborhood schools (Al-Sadan, 2000; Altayar, 2003). In recognition of this dilemma for educating students with disabilities, the Saudi Cultural Mission formed committees to examine the educational curricula and review the quality of teaching in special education programs (Saudi Arabian Cultural Mission, 2006). During this same period, the government also budgeted billions of dollars for the development of teachers' skills in public education (Alnahdi, 2014).

As part of the compulsory curriculum, all students are required to study Islam as a fundamental school subject. The lack of flexibility regarding religious variation has translated to less flexibility regarding the display of outward 
behaviors by students with special needs and restricted the access for all students to inclusive educational settings. The Islamic educational foundation has strong influence on the legal interpretations of special education law, policies regarding treatment of female and male students, and the collaboration between school personnel and parents' responsibility for students with disabilities. Schools in the United States (U.S.) also have had religious effects that greatly influenced curriculum and educational access. To avoid conflicts in the U.S., the government mandated that schools maintain a clear division be between education and religion. For example, prayer has been eliminated in public-funded schools and controversy exists over the recitation of the patriotic pledge of allegiance, which includes religious overtones. Thus, the U.S. school curricula are not guided by any one religious viewpoint, but instead, are directed to adhere to the legal freedoms and federal laws regarding inclusive education for all students. This system is not without other influences that also have directional push and if moved too far from the legal mandate schools and parents in disagreement find themselves in court seeking resolution. Needless to say, most teachers would like to stay out of court battles and focus their energy on teaching.

\subsection{Purpose of the Study}

The purpose of this study was to examine the knowledge of pre-service teachers graduating from a major teacher preparation university in Saudi Arabia concerning special education. Specifically, they responded to a survey about what they knew of special education law existence, if they believed students with disabilities had educational rights, and what they perceived of the legal implementation of educational programs for students with disabilities. This study is essential for the necessary development of the university curriculums for pre-service teachers as Saudi Arabia moves toward an inclusionary education model for students with disabilities.

\subsection{Explore Importance of the Problem}

Given that, both Saudi Arabia and the U.S. have legal mandates for teachers to implement programs for special education (i.e., Law Number 224, 2001; IDEA, 1990, 2004); teacher preparation programs must provide the necessary knowledge and skills for pre-service teachers to implement special education services accurately and legally. It has been suggested that although Law Number 224 has been in existence for over a decade, it is not being practiced in schools and as a result, students with disabilities lack special education services (Alquraini, 2011). It is essential to know if pre-service teachers are aware of the law existence and if they are being prepared in their education programs to implement the law in schools. If they do know that the law exists, then how can they know about what it legally mandates? There are legal policies within both the special education law for Saudi Arabia and the United States that require teachers to be aware of students' rights to an education, discipline procedures, implementation procedures, and whom they believe they can depend upon for support in implementing the law. If they do know the law exists, then it is crucial to find out how open they are to learning about their responsibilities and willingness to implement it in their schools.

In the United States, the rights of children to an inclusive educational environment began as a movement from a civil rights perspective in the 1960s; in Saudi Arabia discussions in government sectors are occurring more and more regarding personal and civil rights of citizens. The civil right of educational knowledge and the use of special education law are increasingly important for teachers in Saudi Arabia as it was in the United States during perspective changes regarding personal and civil rights across the country. Congress passed the first special education law in the U.S. in 1975, and as teachers in schools put the law into daily practice, it underwent repeated amendments for clarification and additions of necessary educational components, such as the requirement of transition planning prior to students with disabilities leaving high school. In the U.S., many of the required and necessary changes emanated from legal battles between parents and schools in courtrooms. In Saudi Arabia, the government developed the law for special education. Courtrooms were not necessary as the vehicle of change, however, there has not yet been a strong drive for the practices outline in the law to be established and/or implement in inclusive or local schools.

In 2001, the Saudi government enacted Law Number 224 -- Regulations of Special Education Programs and Institutes (RSEPI). The RSEPI is closely aligned with the United States' federal program titled, Individuals with Disabilities Education Act (IDEA, 1990). The RSEPI includes 11 Articles that provide for the special education and related services of children with disabilities. It outlines important definitions for teachers, school administrators, other service providers, and families for the education rights of students with disabilities. It includes explanations of the concepts of disability, least restrictive environment, transition services, multidisciplinary team, IEPs, special education teacher, resource room, and other aspects. The knowledge of this law by pre-service teachers is integral to the future education of K-12 students with disabilities. Pre-service teachers are still those that are in university teacher preparation programs, while in-service teachers have graduated and are teaching; in-service teacher may be 
unaware that RSEPI exists and the legal requirement for implementation. Teacher knowledge and ability to implement educational laws will allow opportunity for students with disabilities to receive the same quality of education as their peers without disabilities in Saudi Arabia.

Even though government policies have been legislated for the education of students with disabilities in Saudi Arabia, it cannot be assume that in-service teachers are aware that this is a mandate found within the government regulations. It is critical that pre-service teachers are aware of their obligation to implement the law; otherwise, if they lack training it is counterproductive to the government acknowledgement of the importance of special education and the financial aid commitment to all children with special education needs. Even more so, pre-service teachers' knowledge is essential for the variety of students with special education needs that are educated in Saudi Arabia across more than 1,000 programs in a variety of settings, from special schools with residential facilities to some mainstream schools with support services (Al-Mosa, 2010). In order to increase inclusive education access, teachers must know what support services are to be provided for students with disabilities so they may attend their local schools. Many studies indicate that teacher attitude and their role in the implementation of inclusion in general education schools and classrooms for children with disabilities is one of the most important predictors of successful outcomes (Alur \& Natarajan, 2000; Avradmidis \& Norwich, 2002; Elliott, 2008; Friend \& Bursuck, 2015; Parasuram, 2006; Van Reusen, Shoho, \& Barker, 2001). If teachers in Saudi Arabia know how to include students with disabilities in their classrooms, because they learn about their legal obligations in university coursework and practical experience, the impact of creating successful inclusive educational environments will be greater.

\section{Method}

\subsection{Respondents}

All the respondents to the survey were pre-service teacher candidates from various regions of Saudi Arabia attending their last semester at a large university in Saudi Arabia. There were 55 possible students graduating the semester the survey was made available. A total of 52 respondents provided usable survey information. Three began, but did not complete the survey.

\subsection{Instrument}

The survey was constructed according to guidelines for survey quality outlined by Biemer and Lyberg (2003). The collection of information focused in three areas that would influence future development of university coursework in teacher preparation. The areas were: 1) the level of awareness of pre-service teachers about the rights students with disabilities to an education, particularly those established by Law Number 224;2) the current knowledge of pre-service education teacher candidates regarding their understanding of legal policies that guide their future work with students with disabilities; and 3) pre-service teacher candidates' beliefs concerning school personnel they can depend upon for support in implementing the law. The survey outcome information will promote the reexamination of university curriculum, and the development of courses that will educate pre-service teachers about the RESPI requirements and how they will implement the law for K-12 students with disabilities in Saudi Arabian schools.

\subsection{Data Collection Procedures}

The process for collecting data consisted of the following steps: (a) after the survey was composed, it underwent a rigorous examination for translation accuracy from English to Arabic; (b) the survey was posted through a Survey Monkey website and a link for accessibility was created; and (c) all graduating teacher candidates were sent the link through the university e-mail system. The student e-mail included the purpose of the survey, directions for participation, and dates of survey availability. To ensure no redundancy occurred, each student had a personalized survey \#. Access to the survey was available for one month so the students could complete it at their convenience. In addition, the Vice Dean of College Development arranged computer lab access on campus, ensuring anonymity, for any student needing technological support.

Upon login, the students were informed that their participation was voluntary, anonymous, and that they could discontinue at any point without a negative consequential effect. Yes/no radio buttons were provided so respondents could indicate understanding confirmation of their rights and responsibilities. The survey took approximately 15 minutes to complete. At the conclusion of the survey, the students were given the opportunity to request survey results. 


\section{Results}

The initial section of the survey included demographic and background information. The fifty-two respondents also provided information on their previous work or experience with students with disabilities. The age range of the respondents was from 19 to 31 years old; 22 (42\%) between 19-22 years, 23 (44\%) between 23-26 years, 1 (2\%) between 27-30 years and $4(8 \%)$ were 31 years of age. Two individuals did not include their age. More than one-half, $33(63 \%)$, of the respondents had never worked with students with disabilities and 19 (37\%), had previous work experience with students or had relatives with varying disabilities. For sections 2 through 4, each inquiry stem was followed by response buttons titled, strongly agree, agree, unsure, disagree, and strongly disagree.

The second section of the survey focused on the examination of the awareness that pre-service teachers had about the special education Law Number 224 and legal policies specific to Saudi Arabia. The five inquiry stems that were included were as follows: (1) I know there are special education laws enacted by the Saudi government; (2) It is a right of students with disabilities to go to school; (3) I was taught how to implement the educational laws in my college courses; (4) The Saudi Arabian Constitution protects individuals with disabilities; and (5) I know the educational rights of students with disabilities. Response buttons, strongly agree, agree, unsure, disagree, and strongly disagree, followed each of these inquiry stems.

The pre-service teacher candidates that knew there existed guidance for special education in Saudi Arabian schools indicated a strong intent to encourage and contribute in any developmental movement to protect the educational rights of students with disabilities. They also strongly stated that the students with disabilities must receive their educational rights in schools. However, the majority of the students had not received formal training. They were not clear what their obligation was to students with disabilities or how to specifically implement special education laws in school. In fact, most of them did not think the Saudi Arabia Constitution protected the rights of students with disabilities and did not know the educational rights of students with disabilities. The few who stated that they knew of the Law Number 224 indicated that they intended to implement it in their teaching environments. See Table 1 for specific inquiry stems and number of respondents for each response.

Table 1. General Knowledge about Special Education Laws in Saudi Arabia

\begin{tabular}{|c|c|c|c|c|c|}
\hline Stems & $\begin{array}{l}\text { Strongly } \\
\text { Agree }\end{array}$ & Agree & Unsure & Disagree & $\begin{array}{l}\text { Strongly } \\
\text { Disagree }\end{array}$ \\
\hline $\begin{array}{l}\text { I know there are special education } \\
\text { laws enacted by the Saudi } \\
\text { government. }\end{array}$ & $\begin{array}{c}3 \\
(5.76 \%)\end{array}$ & $\begin{array}{c}8 \\
(15.38 \%)\end{array}$ & $\begin{array}{c}1 \\
(1.92 \%)\end{array}$ & $\begin{array}{c}28 \\
(53.84 \%)\end{array}$ & $\begin{array}{c}12 \\
(23.76 \%)\end{array}$ \\
\hline $\begin{array}{l}\text { It is a right of students with } \\
\text { disabilities to go to school. }\end{array}$ & $\begin{array}{c}34 \\
(65.38 \%)\end{array}$ & $\begin{array}{c}11 \\
(21.15 \%)\end{array}$ & $\begin{array}{c}2 \\
(3.84 \%)\end{array}$ & $\begin{array}{c}5 \\
(9.61 \%)\end{array}$ & $\begin{array}{c}0 \\
(0.00 \%)\end{array}$ \\
\hline $\begin{array}{l}\text { I was taught how to implement the } \\
\text { educational laws in my college } \\
\text { courses. }\end{array}$ & $\begin{array}{c}2 \\
(3.84 \%)\end{array}$ & $\begin{array}{c}6 \\
(11.53 \%)\end{array}$ & $\begin{array}{c}6 \\
(11.53 \%)\end{array}$ & $\begin{array}{c}10 \\
(19.23 \%)\end{array}$ & $\begin{array}{c}28 \\
(53.84 \%)\end{array}$ \\
\hline $\begin{array}{l}\text { The Saudi Arabian Constitution } \\
\text { protects individuals with disabilities. }\end{array}$ & $\begin{array}{c}4 \\
(7.69 \%)\end{array}$ & $\begin{array}{c}7 \\
(13.46 \%)\end{array}$ & $\begin{array}{c}10 \\
(19.23 \%)\end{array}$ & $\begin{array}{c}23 \\
(44.23 \%)\end{array}$ & $\begin{array}{c}8 \\
(15.38 \%)\end{array}$ \\
\hline $\begin{array}{l}\text { I know the educational rights of } \\
\text { students with disabilities. }\end{array}$ & $\begin{array}{c}1 \\
(1.92 \%)\end{array}$ & $\begin{array}{c}8 \\
(15.38 \%) \\
\end{array}$ & $\begin{array}{c}3 \\
(5.76 \%) \\
\end{array}$ & $\begin{array}{c}23 \\
(44.23 \%) \\
\end{array}$ & $\begin{array}{c}18 \\
(34.61 \%)\end{array}$ \\
\hline
\end{tabular}

Section 3 of the survey focused on the knowledge of the pre-service teacher candidates toward the legal policies that would guide their work for special education and its implementation in schools. This section included six inquiry stems: (1) I know how to deal with my students according to special education laws; (2) I want to know more about special educational laws, (3) I believe all teachers should receive special training about special education laws; (4) The law of special education is important for me to know; (5) It is important for me to implement the special education law; and (6) I have knowledge of the primary procedures of special education in Saudi Arabia.

It appears that most of the teachers who had previous experiences in their work or personal lives with students with disabilities anticipated having them in classes in the future and that they would willingly work with them to provide 
their educational rights. These same teachers also indicated a desire to learn more about special education laws. There was an overriding expression of the importance of special education and that teachers should know and learn about students with disabilities. Several teachers wrote that they wanted to know how to implement special education. The desire to know more is important to note as the majority of respondents did not know the primary procedures of implementing the special education laws in schools or that the law existed. The awareness of the need to educate all students is a positive finding among graduating pre-service teacher candidates. See Table 2 for the specific response details.

Table 2. Personal Experience with Special Education Laws in Saudi Arabia

\begin{tabular}{|c|c|c|c|c|c|}
\hline Statement & $\begin{array}{l}\text { Strongly } \\
\text { Agree }\end{array}$ & Agree & Unsure & Disagree & $\begin{array}{l}\text { Strongly } \\
\text { Disagree }\end{array}$ \\
\hline $\begin{array}{l}\text { I can deal with my students according } \\
\text { to special education laws. }\end{array}$ & $\begin{array}{c}3 \\
(5.76 \%)\end{array}$ & $\begin{array}{c}5 \\
(9.61 \%)\end{array}$ & $\begin{array}{c}8 \\
(15.38 \%)\end{array}$ & $\begin{array}{c}14 \\
(26.92 \%)\end{array}$ & $\begin{array}{c}16 \\
(30.76 \%)\end{array}$ \\
\hline $\begin{array}{l}\text { I want to know more about special } \\
\text { educational laws. }\end{array}$ & $\begin{array}{c}36 \\
(69.23 \%)\end{array}$ & $\begin{array}{c}12 \\
(23.07 \%)\end{array}$ & $\begin{array}{c}0 \\
(0.00 \%)\end{array}$ & $\begin{array}{c}4 \\
(7.69 \%)\end{array}$ & $\begin{array}{c}0 \\
(0.00 \%)\end{array}$ \\
\hline $\begin{array}{l}\text { I believe all teachers should receive } \\
\text { special training about special } \\
\text { education laws. }\end{array}$ & $\begin{array}{c}27 \\
(51.92 \%)\end{array}$ & $\begin{array}{c}22 \\
(42.30 \%)\end{array}$ & $\begin{array}{c}2 \\
(3.84 \%)\end{array}$ & $\begin{array}{c}1 \\
(1.92 \%)\end{array}$ & $\begin{array}{c}0 \\
(0.00 \%)\end{array}$ \\
\hline $\begin{array}{l}\text { The law of special education is } \\
\text { important for me to know. }\end{array}$ & $\begin{array}{c}27 \\
(51.92 \%)\end{array}$ & $\begin{array}{c}22 \\
(42.30 \%)\end{array}$ & $\begin{array}{c}2 \\
(3.84 \%)\end{array}$ & $\begin{array}{c}1 \\
(1.92 \%)\end{array}$ & $\begin{array}{c}0 \\
(0.00 \%)\end{array}$ \\
\hline $\begin{array}{l}\text { It is important for me to implement } \\
\text { special education laws. }\end{array}$ & $\begin{array}{c}27 \\
(51.92 \%)\end{array}$ & $\begin{array}{c}22 \\
(42.30 \%)\end{array}$ & $\begin{array}{c}2 \\
(3.84 \%)\end{array}$ & $\begin{array}{c}1 \\
1.92 \%)\end{array}$ & $\begin{array}{c}0 \\
(0.00 \%)\end{array}$ \\
\hline $\begin{array}{l}\text { I have knowledge of the primary } \\
\text { procedures of special education in } \\
\text { Saudi Arabia. }\end{array}$ & $\begin{array}{c}4 \\
(7.69 \%)\end{array}$ & $\begin{array}{c}2 \\
(3.84 \%)\end{array}$ & $\begin{array}{c}2 \\
(3.84 \%)\end{array}$ & $\begin{array}{c}20 \\
(38.46 \%)\end{array}$ & $\begin{array}{c}24 \\
(46.15 \%)\end{array}$ \\
\hline
\end{tabular}

Section 4 examined the perceptions that the pre-service teacher candidates had regarding other school personnel knowledge of the implementation of special education in schools and if they believed parents of students with disabilities knew about their involvement in their child's special education program. The section included five inquiry stems eliciting what they believed others knew and/or did regarding special education: (1) I believe the school administrators try to make others aware of the educational rights of students with disabilities; (2) I believe the school administration provides needed information about education laws; (3) I believe parents know that the law allows them to be involved in planning the education of their children with disabilities; (4) I believe the schools in Saudi Arabia provide educational rights to students with disabilities; and (5) I believe the laws of special education are important and are implemented in schools by teachers.

The pre-service teacher candidates saw a discrepancy between what they stated was important for students with disabilities and what they perceived enacted in schools. The majority of the respondents did not believe that the administrators overseeing special education in schools were implementing the laws. In addition, they expressed that it was doubtful that those same administrators provided teachers with the information about special education laws. It would be important to explore in future research if administrators were aware of Law Number 224 and/or received training in their preparation programs for the implementation. See Table 3 for respondents' collective beliefs about the support and knowledge of special education information provided in schools. 
Table 3. Knowledge of Others

\begin{tabular}{|c|c|c|c|c|c|}
\hline Statements & $\begin{array}{c}\text { Strongly } \\
\text { Agree }\end{array}$ & Agree & Unsure & Disagree & $\begin{array}{l}\text { Strongly } \\
\text { Disagree }\end{array}$ \\
\hline $\begin{array}{l}\text { I believe the school administrators try to } \\
\text { make others aware of the educational } \\
\text { rights of students with disabilities. }\end{array}$ & $\begin{array}{c}0 \\
(0.00 \%)\end{array}$ & $\begin{array}{c}3 \\
(5.76 \%)\end{array}$ & $\begin{array}{c}10 \\
(19.23 \%)\end{array}$ & $\begin{array}{c}25 \\
(48.07 \%)\end{array}$ & $\begin{array}{c}14 \\
(26.92 \%)\end{array}$ \\
\hline $\begin{array}{l}\text { I believe the school administration } \\
\text { provides needed information about } \\
\text { education laws. }\end{array}$ & $\begin{array}{c}0 \\
(0.00 \%)\end{array}$ & $\begin{array}{c}3 \\
(5.76 \%)\end{array}$ & $\begin{array}{c}6 \\
(11.53 \%)\end{array}$ & $\begin{array}{c}28 \\
(53.84 \%)\end{array}$ & $\begin{array}{c}15 \\
(28.84 \%)\end{array}$ \\
\hline $\begin{array}{l}\text { I believe parents know that the law } \\
\text { allows them to be involved in planning } \\
\text { the education of their children with } \\
\text { disabilities. }\end{array}$ & $\begin{array}{c}1 \\
(1.92 \%)\end{array}$ & $\begin{array}{c}7 \\
(13.46 \%)\end{array}$ & $\begin{array}{c}10 \\
(19.23 \%)\end{array}$ & $\begin{array}{c}13 \\
(25 \%)\end{array}$ & $\begin{array}{c}21 \\
(40.38 \%)\end{array}$ \\
\hline $\begin{array}{l}\text { I believe the school personnel in Saudi } \\
\text { Arabia provide educational rights to } \\
\text { students with disabilities. }\end{array}$ & $\begin{array}{c}0 \\
(0.00 \%)\end{array}$ & $\begin{array}{c}1 \\
(1.92 \%)\end{array}$ & $\begin{array}{c}13 \\
(25 \%)\end{array}$ & $\begin{array}{c}27 \\
(51.92 \%)\end{array}$ & $\begin{array}{c}11 \\
(21.15 \%)\end{array}$ \\
\hline $\begin{array}{l}\text { I believe the laws of special education } \\
\text { are important and are implemented in } \\
\text { schools by teachers. }\end{array}$ & $\begin{array}{c}27 \\
(51.92 \%)\end{array}$ & $\begin{array}{c}22 \\
(42.30 \%)\end{array}$ & $\begin{array}{c}2 \\
(3.84 \%)\end{array}$ & $\begin{array}{c}1 \\
(1.92 \%)\end{array}$ & $\begin{array}{c}0 \\
(0.00 \%)\end{array}$ \\
\hline
\end{tabular}

The survey concluded with one open-ended question to allow respondents to express their knowledge not addressed about special education in Saudi Arabia. They were asked, What do you know about the Special Education Law Number 224? Thirty-three (63.46\%) respondents provided responses to this question. Nineteen (36.54\%) responses were not useable as they did not address the question. Of the 33 usable responses to this question two categories emerged; those who knew of the law and those who did not know of the law. Based on the responses, 6 respondents knew about Special Education Law Number 244 and 23 respondents did not know about the Special Education Law Number 224. Of those that knew of the law, they expressed a desire to know more as they indicated that their knowledge was only at the level that the law existed, not at the level of implementation of specific content of their responsibility. The majority of those who indicated that they did not know the law existed expressed to have more information and support to use it to support the families of children with disabilities. The participants conveyed that the missing information about special education created a ripple effect, resulting in a lack of educational outcomes for students with disabilities. They wrote that this punitive result was caused by the lack of knowledge teachers had, which in turn, lead to a lack of information given to parents regarding the educational rights of their children. Many expressed that students would suffer due to the limited implementation of special education and supply of information about students' and families' legal rights.

As mentioned, only 6 respondents indicated that they knew specifically about Law Number 224. Two of them knew it as a special education law which was enacted by the Saudi government, but they had never read or seen it implemented in schools. Three of the 6 thought it was a law about education but had no detailed knowledge about it. One respondent believed it was a law about special education but was unsure of his response. In addition, most of the respondents said they had never received information in their teacher preparation programs on the special education programs or the laws that would guide their work with students who had special education needs. When analyzing how the majority of teacher candidates had answered the last inquiry stem in Section 3, the researchers noted it was vastly different from the other responses given by the candidates. It was concluded that they interpreted the stem to mean when special education is implemented in schools it is by teachers and it was extremely important that they have the knowledge to do so. Given their previous responses and their open-ended comments, it would have been incongruent to think they were saying they were currently knowledgeable and ready to implement special education laws in schools.

\section{Discussion}

The development of teacher training programs that include information about the educational rights of students with disabilities is extremely important. The results of this study showed that pre-service education teacher candidates do 
not have a good knowledge base, but do have enough information to know that they want to know more and believe that students should be educated in their classrooms. However, it was found the preservice teacher candidates who will have students with disabilities in their classrooms have not received more than cursory information in their preparation program on the subject. If Saudi Arabia wants to see the government vision and financial support agenda come to fruition there will need to be collaboration between university/college personnel and school administrations. This collaboration will be necessary in order for high quality services to be provided by teachers in schools.

It is already a wide-spread statement amongst the participants of this survey that students with disabilities have just as much right to an education as those students without disabilities. Students with disabilities will need to have opportunity to receive individualized education programs and services in order to develop their skills, live independent lives, contribute to their communities, as well as to do these activities within the least restrictive environment, which would be their neighborhood schools. The empowerment of students with disabilities to live lives of quality can come through improving university teacher preparation programs by giving them information on how to implement Law Number 224 in the school systems.

It is highly recommended that special education teacher preparation programs at universities in Saudi Arabia create courses focused on the historical and evolving special education laws, regulations, policies, and procedures that affect the lives of youth with disabilities and their families. The government has invested large amounts of resources and it certainly appears they are expecting positive impact on the future for individuals with disabilities in their country. The public media has highlighted the need for inclusive settings and educational programs that prepare individuals for quality lives upon graduation. As has been seen, the special education law in the U.S., IDEA, once openly enacted, changed educational delivery in K-12 schools and required teacher preparation programs in the U.S. to create curriculum to train teachers in implementation and delivery of special education accordingly. Since the Saudi Arabian Law Number 224 closely reflects the same guidelines provided in IDEA, it will be incumbent upon university programs in Saudi Arabia to prepare teachers in the implementation and delivery of special education according to the guidelines given in Law Number 224 if they are to use the law for the benefit of individuals with disabilities. Specifically, a course for pre-service teachers on how to demonstrate the knowledge of the components necessary to implement special education programs according to Law Number 224. These university courses, given the strong influence of Islam in Saudi Arabia, must include discussion of how religious perspectives affect the interpretation of the law, the implementation of inclusive practices in schools for students with disabilities, and how teachers approach the teaching of students in alignment with Law Number 224. Just as IDEA evolved in the U.S. to meet the changing educational needs, it is foreseeable that Law Number 224 will need amendments as implementation and daily practice of it in schools is questioned and needs clarifications.

\section{References}

Almadina Newspaper (2011, May 29). Education: 80\% degrees of the teachers incentives based on students' performance. Retrieved on Alnahdi, G.H. (2014). Educational change in Saudi Arabia. Journal of International Education Research, 10(1), 1-6.

Al-Mousa, N. A. (2010). The experience of the Kingdom of Saudi Arabia in mainstreaming students with special educational needs in public schools (a success story). The Arab Bureau of Education for the Gulf States, Saudi Arabia: Riyadh.

Alnahdi, G. H. (2014). Educational change in Saudi Arabia. Journal of International Education Research, 10(1), 1-6.

Alquraini, T. (2011). Special education in Saudi Arabia: Challenges, perspective, future possibilities. International Journal of Special Education 26(2), 149-159.

Al-Sadan, I. (2000). Educational assessment in Saudi Arabian schools. Assessment in Education: Principles, Policy \& Practice, 7(1), 143-155.

Altayar, B. (2003). Problems in teaching. College of Education, King Saud University, Saudi Arabia.

Alur, M., \& Natarajan, P. (2000). Developing sustainable educational inclusion policy and practice: UK, South Africa, Brazil and India: an international research project - final report. (Mumbai, Spastics Society of India).

Avramidis, E., \& Norwich, B. (2002). Teachers' attitudes towards integration / inclusion: a review of the literature. European Journal of Special Needs Education, 17(2), 129-147. http://dx.doi.org/10.1080/08856250210129056

Biemer, P.P., \& Lyberg L.E. (2003). Introduction to Survey Quality. Chicheser, England: Wiley.

Elliot, S. (2008). The effect of teachers; attitude toward inclusion on the practice and success levels of children with 
and without disabilities in physical education. International Journal of Special Education, 23(3), 48-55.

Friend, M., \& Bursuck, W. D. (2015). Including students with special needs: A practical guide for classroom teachers. Upper Saddle River, NJ: Pearson Inc.

Individuals with Disabilities Education Act, 20 U.S.C. $§ 1400$ (1990, 2004).

Parasuram, K. (2006). Variables that affect teachers' attitudes towards disability and inclusive education in Mumbai, India. Disability \& Society, 21(3), 231-242. http://dx.doi.org/10.1080/09687590600617352.

Rugh, W.A. (2002). Education in Saudi Arabia: Choice and constraints. Middle East Policy, 9(2), 40-55.

Saudi Arabian Cultural Mission. (2006). Educational system in Saudi Arabia. Washington DC, Saudi Cultural Mission. Retrieved from http://www.sacm.org/Publicaions/58285_Edu_complete.pdf

Van Reusen, A. K., Shoho, A. R., \& Barker, K. S. (2001). High school teacher attitudes toward inclusion. The High School Journal, 7-20. 